\title{
PSMC2 Gene
}

National Cancer Institute

\section{Source}

National Cancer Institute. PSMC2 Gene. NCI Thesaurus. Code C106089.

This gene is involved in the regulation of proteasomal activity. 